\title{
Use of sparingly soluble micronutrients sources for citrus production
}

\author{
Luisa Oliveira Macedo ${ }^{1}$, Rodrigo Marcelli Boaretto ${ }^{1}$, Rodrigo Candido Jacobassi ${ }^{1}$, \\ Natália Fernandes Carr ${ }^{1}$, José Antonio Quaggio ${ }^{2} \&$ Dirceu Mattos-Jr. ${ }^{1}$
}

\begin{abstract}
SUMMARY
Despite a diverse array of micronutrient fertilizers is manufactured in the world, plant nutritional disorders remain a challenge for many growers. In Brazil, boron (B), zinc ( $\mathrm{Zn}$ ) and manganese $(\mathrm{Mn})$ are the most limiting micronutrients to citrus production. In the soil, B is prone to leaching losses and the metallic nutrients are less available to the plants due to the lower mobility and high fixation to the colloids of the clay fraction. Therefore, foliar applications have represented a major strategy for micronutrient supply to citrus trees, even though; efficiency of such practice is still debated. Differential agronomic responses of sources are attributed to the companion ion of the chemical species, the solubility in water and the particle size of the fertilizer granules. The purpose of this review is to discuss the role of sparingly soluble fertilizer in the nutrition of citrus plants. The development of suspension concentrates, based on sparingly soluble inorganic micronutrient sources, is the single most significant advance in technology recently that has resulted in a wide range of commercial products for growers. The sparingly soluble sources when applied to the soil reduce adsorption of the metal. In foliar sprays, the particles adhered to the leaf surface can serve as a solid phase to restore the micronutrient supply during a prolonged growth phase of the leaf. In both situations, the gradual release of the nutrients may reduce absorption rate and the risk of phytotoxicity. Satisfactory results for the use of sparingly soluble sources were demonstrated, but further studies are necessary to validate the efficacy of foliar application of sparingly soluble sources, which will enable the registration of these products with the official regulatory agencies and allow the recommendation to the citrus growers.
\end{abstract}

Index terms: fertilizer efficacy, microparticles, plant nutrition, foliar spray.

\section{Uso de fontes de micronutrientes pouco solúveis para a produção de citros}

\section{RESUMO}

Apesar da variedade de fertilizantes contendo micronutrientes fabricadas no mundo, os distúrbios nutricionais das plantas continuam sendo um desafio para muitos produtores. No Brasil, o boro (B), o zinco (Zn) e o manganês (Mn) são os micronutrientes mais limitantes para a produção de citros. No solo, o B é propenso a perdas por lixiviação e os micronutrientes metálicos estão menos disponíveis para as plantas devido à menor mobilidade e a maior fixação a matriz coloidal do solo. Portanto, as adubações foliares representaram uma estratégia importante para o fornecimento de

${ }^{1}$ Centro de Citricultura Sylvio Moreira, Instituto Agronômico, Cordeirópolis, SP, Brazil

${ }^{2}$ Centro de Solos e Recursos Ambientais, Instituto Agronômico, Campinas, SP, Brazil

Corresponding author: Rodrigo Marcelli Boaretto, Centro de Citricultura Sylvio Moreira, Instituto Agronômico, Rod. Anhanguera, Km 158, CP 04, CEP 13490-970, Cordeirópolis, SP, Brazil. E-mail: boaretto@iac.sp.gov.br 
micronutrientes às árvores cítricas, embora a eficiência dessa prática ainda seja debatida. As respostas agronômicas diferenciais das fontes são atribuídas ao íon complementar das espécies químicas, à solubilidade em água e ao tamanho de partícula dos grânulos de fertilizantes. O objetivo desta revisão é discutir o papel de fontes fertilizantes pouco solúveis na nutrição de plantas cítricas. O desenvolvimento de suspensões concentradas, produzidas a partir de fontes de micronutrientes inorgânicos pouco solúveis, é o avanço mais recente de tecnologia que resultou em uma ampla gama de produtos comerciais para produtores. As fontes pouco solúveis quando aplicadas no solo reduzem a adsorção do metal. Em pulverizações foliares, as partículas aderidas à superfície da folha podem servir como uma fase sólida para restaurar o suprimento de micronutrientes durante uma fase de crescimento prolongada da folha. Em ambas as situações, a liberação gradual dos nutrientes pode reduzir a taxa de absorção e o risco de fitotoxicidade. Resultados satisfatórios foram demonstrados para o uso de fontes pouco solúveis, contudo, mais estudos ainda são necessários para comprovar a eficácia da aplicação foliar dessas fontes, o que viabilizará o registro desses produtos junto às agências reguladoras oficiais e permitirá a recomendação aos citricultores.

Termos de indexação: eficiência fertilizante, micropartículas, nutrição mineral de plantas, adubação foliar.

\section{INTRODUCTION}

Micronutrients are supplied in smaller amounts compared with macronutrients to newly planted citrus trees, even though shortage of micronutrients can affect plants as a result of vigorous growth of canopy, and consequently micronutrient deficiencies can affect orchards. Therefore, a balanced supply between macronutrients and micronutrients is needed for optimum tree development and fruit yield. Citrus micronutrient deficiencies are commonly observed on highly weathered tropical soils, uncultivated soils, shallow soils with high water table, extremely sandy areas, and calcareous soils originated from marine sediments (Quaggio \& Piza, 2001; Zekri \& Obreza, 2003).

Boron (B), zinc ( $\mathrm{Zn}$ ) and manganese (Mn) are the most limiting micronutrients to citrus production in Brazil, due to low contents in the soil rock parent material and to the specific adsorption that occurs with the colloidal matrix of cultivated soils. Furthermore, the availability of cationic micronutrients is still regulated by the soil reaction, being reduced at high $\mathrm{pH}$ values (Lindsay, 1979).

There is a range of micronutrient fertilizer products manufactured in the world, even though their distribution and affordability varies with geographical regions. Thus, micronutrient disorders still remain problematic for many growers (Bell \& Dell, 2008). Studies continue to be developed to improve the application of micronutrients in agricultural systems. There are few reports that demonstrate the effectiveness of micronutrient applications via soil, since these are preferentially applied via foliar, because of the easiness of distribution of small quantities and the possibility to mix with pesticides (Fageria et al., 2009;
Hippler et al., 2015a). However, foliar applications offers practical limitations such as: (i) a single application is rarely performed for micronutrients and this application is always associated with other cultural practices, which are usually conducted at the moment for the best control of pests / diseases and not necessarily in the moment of greater demand of micronutrients by the plant; (ii) the micronutrients have low mobility in the plant, being necessary new applications to the main flushes of growth; (iii) low amounts of micronutrients shall be sprayed in the plants to avoid toxicity, mostly associated with saline effects of products causing leaf injuries; (iv) in addition to all these factors, with the aim of reducing production costs citrus growers have also reduced spraying volumes per application in citrus groves, which aggravates cited problems (Boaretto et al., 2002, 2004; Clapp, 2009; Fernández et al., 2013).

The development of concentrated suspensions, based on sparingly soluble inorganic micronutrient sources (Moran, 2006) is the single most significant advance in technology, which has resulted in a wide range of commercial products available to the growers (Bell \& Dell, 2008).

In order to improve the efficiency of sparingly soluble sources of micronutrients, those are mainly used as micro or nanoparticles, nevertheless, a better understanding of their effectiveness and mode of use is required, especially for foliar application. In the Brazilian legislation, the fertilizers registered for foliar fertilization must present completely soluble micronutrients what does not allow registration of these for use. This review discuss information that demonstrate advantages and disadvantages on the use of sparingly soluble sources in the citriculture that 
can contribute with decision making of practical and legislative purposes associated to the fertilizer industry and growers.

\section{FERTILIZER SOURCES: PHYSICAL AND CHEMICAL CHARACTERISTICS}

Fertilizers containing micronutrients are grouped into inorganic, synthetic chelates, organic complexes and gel based frits. Among the most common inorganic sources are oxides, carbonates, phosphates, oxysulfates, sulfates, chlorides and nitrates, of which the last three cited are the most used sources for foliar applications in citrus production, and found for sale as a series of foliar fertilizers varying in concentrations not only of micro but also of macronutrients (Fagundes et al., 2010; Quaggio et al., 2010). For micronutrient supply via soil, the sulfates are the most commonly used fertilizers due to their physical properties that allow them to be mixed with other fertilizers (Shaver et al., 2007).
The salts with sulfates, chlorides and nitrates are soluble in water and the oxides and carbonates are sparingly soluble in water. Oxysulfates are oxides of copper $(\mathrm{Cu})$, $\mathrm{Mn}$ and $\mathrm{Zn}$ with different degrees of solubility in water depending on the amounts of sulfuric acid added in their production route (Table 1). Water solubility of $\mathrm{ZnO}$ is low and depends on the physical and chemical nature of the product, which are still influenced by manufacturing process. For instance, the maximum solubility of $\mathrm{ZnO}$ estimated by the dissolution kinetics of $\mathrm{Zn}\left(\mathrm{Zn}^{2+}\right)$ ions from oxide powders is a function of $\mathrm{pH}$ and is affected by the product purity and the size of the powder particles (McBeath \& McLaughlin, 2014). In that case, low solubility sources with smaller particle sizes favor plant nutrient uptake due to the larger contact surface (Volkweiss, 1991; Abreu et al., 1996). Crushed B ores, particularly colemanite and ulexite, for example, have been used as fertilizers. Notwithstanding, the uncertainty about the availability of micronutrients from sparingly soluble sources, due to varying composition and amounts of insoluble materials, has limited their use for annual

Table 1. Water solubility of inorganic micronutrients sources for the fertilizer industry

\begin{tabular}{|c|c|c|c|}
\hline Compound & Formula & Element content $(\%)$ & Water solubility \\
\hline \multicolumn{4}{|c|}{ Boron - crushed ores } \\
\hline Colemanite & $2 \mathrm{MgO} \cdot \mathrm{B}_{2} \mathrm{O}_{3} \cdot \mathrm{H}_{2} \mathrm{O}$ & variable & Slightly soluble \\
\hline Datolite & $2 \mathrm{CaO} \cdot \mathrm{B}_{2} \mathrm{O}_{3} \cdot 2 \mathrm{SiO}_{2} \cdot \mathrm{H}_{2} \mathrm{O}$ & variable & Slightly soluble \\
\hline Hydroboracite & CaO.MgO. $3 \mathrm{~B}_{2} \mathrm{O}_{3} \cdot 6 \mathrm{H}_{2} \mathrm{O}$ & variable & Slightly soluble \\
\hline Calcium borate & $\mathrm{CaB}_{3} \mathrm{O}_{4}(\mathrm{OH})_{3} \cdot \mathrm{H}_{2} \mathrm{O}$ & & Sparingly soluble \\
\hline \multicolumn{4}{|c|}{ Copper } \\
\hline Cuprous oxide & $\mathrm{Cu}_{2} \mathrm{O}$ & 89 & Sparingly soluble \\
\hline \multicolumn{4}{|l|}{ Manganese } \\
\hline Manganese carbonate & $\mathrm{MnCO}_{3}$ & 47 & Sparingly soluble \\
\hline Manganous oxide & $\mathrm{MnO}$ & 77 & Insoluble \\
\hline Manganese dioxide & $\mathrm{MnO}_{2}$ & 63 & Insoluble \\
\hline Manganese oxysulfate & $\mathrm{xMnSO}_{4} \cdot \mathrm{xMnO}$ & $30-50$ & Variable \\
\hline \multicolumn{4}{|l|}{ Molybdenum } \\
\hline Molybdenum trioxide & $\mathrm{MoO}_{3}$ & 60 & Slightly soluble \\
\hline \multicolumn{4}{|l|}{ Zinc } \\
\hline Basic zinc sulfate & $\mathrm{ZnSO}_{4} \cdot 4 \mathrm{Zn}(\mathrm{OH})_{2}$ & 55 & Slightly soluble \\
\hline Zinc oxide & $\mathrm{ZnO}$ & $50-80$ & Sparingly soluble \\
\hline
\end{tabular}

The term "sparingly soluble" means that the product is not totally insoluble, particularly when present in small particle sizes (with a large surface area). This terminology reflects recent technological advances in micronutrient product formulation (Moran, 2004). Slightly soluble are products less soluble them the sparingly soluble. Source: Adapted from Bell \& Dell (2008). 
species, but not in perennial crops (Bell \& Dell, 2008), such as citrus and coffee.

The immediate effectiveness of micronutrient oxide fertilizer sources can be low and, to be effective over time, they should be evenly applied and mixed into the soil to maximize the contact; on the other hand they can be ineffective when applied in a granular form. Several studies have published results showing that the effectiveness of granular $\mathrm{Zn}$ oxysulfates is related to their water solubility. It has been recommended that the water-soluble $\mathrm{Zn}$ content be above $40-50 \%$ of the total $\mathrm{Zn}$ to be effective to supply Zn (Gangloff et al., 2002; Slaton et al., 2005). In a few countries, metal slags are used as a source of micronutrients, particularly $\mathrm{Cu}$ (Bell \& Dell, 2008).

An important aspect to choose the source of micronutrient for leaf spraying is the deliquescent point (POD) of the fertilizers, which is defined as the relative humidity value at which the salt becomes a solute, so the lowest is the POD of a salt, the earliest it will dissolve after exposure to ambient humidity (Fernández \& Eichert, 2009). The sparingly soluble sources, with POD above relative humidity, when applied to the leaves, theoretically prevail as solutes and the penetration of the leaf is prolonged. The effectiveness of products with a high POD can be improved by the use of adjuvants with wetting properties. Salts with low POD may be more effective in the early stages of application, but may be more prone to cause phytotoxicity (Fernández et al., 2013).

Sparingly soluble sources of micronutrients have been studied primarily in the area of nanotechnology, where nano-materials can be used for the design of new fertilizers (Naderi et al., 2011). This new technical can be used to release nutrients gradually according to plant demand, or be designed to prevent the immobilization of nutrients in the soil, allowing plants to take up the nutrient directly, and thereby improve the nutrient uptake (DeRosa et al., 2010). The size of particles found in fertilizers with Mn carbonate and $\mathrm{Zn}$ oxide sources for soil application were suspensions with $90 \%$ of the particles in size 150-300 and 200-800 nm, respectively (Hippler et al., 2015a), and those are considered microparticles. Materials that are smaller than $100 \mathrm{~nm}$ in at least one dimension are generally classified as nanomaterials (Wiesner et al., 2006) (Figure 1).

The small size of the nanoparticles promotes a larger surface area that modifies the properties of the product, this technology associated with fertilizers can release the nutrient in a prolonged and controlled manner, ensuring the sustainable development of plants, economic benefits, and environmental safety when applied in soil (Subramanian \& Sharmila Rahale, 2012) and foliar (Mosanna \& Khalilvand, 2015). Also, the micronutrient supply can be done in smaller amounts than when using common fertilizers (Batsmanova et al., 2013; Subramanian et al., 2015).

\section{WAYS OF SUPPLYING MICRONUTRIENTS}

The application of soluble and sparingly soluble sources in young orange plants showed that fertilizers containing $\mathrm{Mn}$ and $\mathrm{Zn}$ applied in the soil were able to increase the levels of these micronutrients in the roots system and especially in the new growing flushes developed after fertilization, which represent the main nutrient sinks in the plants. Although the plants exhibited lowest concentrations of $\mathrm{Mn}$ and $\mathrm{Zn}$ in the leaves when receiving either $\mathrm{Mn}$ carbonate or $\mathrm{Zn}$ oxide, respectively, compared with sulfates, the less soluble sources promoted higher dry mass production of roots, leaves, and branches

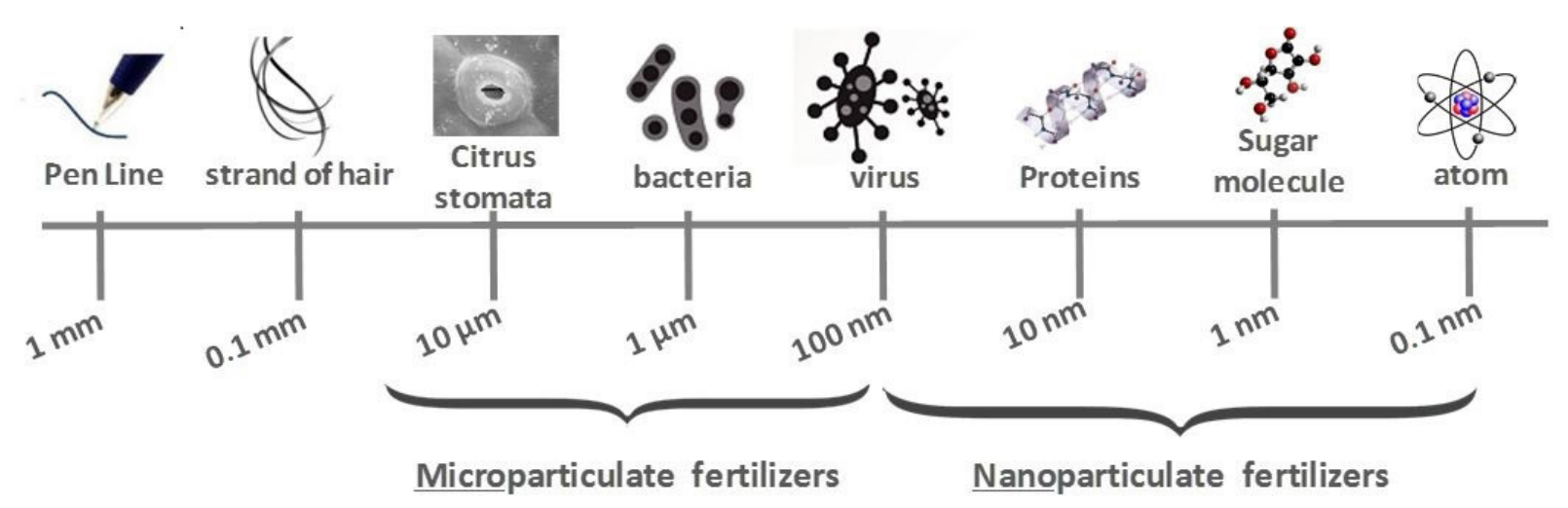

Figure 1. Scale of microparticles and nanoparticles. Source: Authors. 
in response to fertilizer applications in a sandy loam soil. Also, the plants grown in the soil with the highest rates of $\mathrm{Mn}$ and $\mathrm{Zn}$ by the sulfates, showed visual symptoms of metal toxicity, mainly to $\mathrm{Mn}$, characterized by necrotic spots on leaves (Hippler et al., 2015a).

In the soil, the metallic nutrients are less available to the plants due to the lower mobility and higher adsorption to the colloids of the clay fraction. The less soluble sources like oxides, carbonates or phosphates when applied to the soil, gradually release the nutrients into the soil solution, which may reduce absorption rate and consequently the risk of phytotoxicity, and in addition, also reduce adsorption of the metal to the soil (Bradl, 2004; McBeath \& McLaughlin, 2014).

In seed treatment, the sparingly sources provide less nutrients to plants compared to the soluble sources, but avoid symptoms of toxicity, like as occurred in citrus fertilization (Hippler et al., 2015a), since when the effectiveness of $\mathrm{ZnSO}_{4}$ and $\mathrm{ZnO}$ were compared in supplying $\mathrm{Zn}$ for maize seeds, authors verified that the first one was able to promote higher uptake of $\mathrm{Zn}$ by plants, however, reducing seedling emergence percentage, probably due to salinity, while $\mathrm{Zn}$ oxide did not present such harmful effect (Prado et al., 2007). Similar results were found by testing $\mathrm{Cu}$ sulfate formulations in maize seed treatments, with a high uptake of $\mathrm{Cu}$ by plants accompanied by toxic effects to seeds (Luchese et al., 2004). Seed treatment with $\mathrm{CuCO}_{3}$ and $\mathrm{ZnO}$ increased both, root and shoot concentration and accumulation of $\mathrm{Cu}$ and $\mathrm{Zn}$ in maize seedlings (Dias \& Cicero, 2016).

The management of micronutrients in the field is carried out with the supply of these nutrients via soil or sprayed in the leaves. In the soil, as previously reported, nutrients applied, especially metals, are less available to plants, and the supply is difficult due to the variation in micronutrient availability in soil solution, which is dependent on the type of soil (Alloway, 2008; Hippler et al., 2015b). For citrus the efficiency of Zn fertilizers depends on the fertilizer source and the soil texture, since the $\mathrm{Zn}$ fertilizer use efficiency, based on the recovery rate in the plants, was as high as $4 \%$ when a water-soluble $\mathrm{Zn}$ source was used in a sandy loam soil, but it was only $0.1 \%$ when a less soluble $\mathrm{ZnO}$ source was used on the clay soil with the highest $\mathrm{Zn}$ adsorption capacity. All these later must be taken into account by guidelines for fruit crop fertilization via soil, in substitution or complementation of foliar fertilization (Hippler et al., 2015b).

Significant response in increase foliar $\mathrm{Zn}$ to field-grown trees was observed only in the third year after initiation the application of $\mathrm{ZnSO}_{4}$ in a medium-texture Oxisol (Quaggio et al., 2003), the same was found for coffee trees, since when applied high amounts of $\mathrm{Zn}\left(600 \mathrm{~g} \mathrm{Zn} \mathrm{plant}^{-1}\right)$ in the soil, it increased $\mathrm{Zn}$ in leaves and toxicity symptoms was found only 2 years after application, been the $\mathrm{Zn}$ retained in wood parts (Tezotto et al., 2012). For citrus, the accumulation of ${ }^{68} \mathrm{Zn}$ labeling also occurred mainly in the roots and woody organs, which may be important reserve organs for this nutrient (Hippler et al., 2015b). This difficult to uptake metals by the leaves when applied to the soil, justified the complementation by foliar application, mainly for metallic micronutrients (Quaggio et al., 2003). Thus, the application of micronutrients in the soil should be thought in a preventive way, while the application of micronutrients via foliar can be thought also in a corrective way, since it acts quickly in the peak of demand (Fernández et al., 2013). In Brazil, the guidelines for citrus growers recommend preventive micronutrient applications in soil and leaves, which have increased fruit production (Quaggio et al., 2010). In other places, such as Florida (USA), micronutrient foliar application is based on visual deficiency symptoms or low leaf analysis values (Obreza et al., 2010). The preventive effect of the application is important, once when symptoms of micronutrients deficiency in the plants are observed, damages caused at the cellular level has already occurred (Bell \& Dell, 2008)

Foliar application is an effective method and the most widely used for micronutrients application in the citriculture, due to the easiness of distribution of small amounts of micronutrients in large areas (Camargo, 1991), as well as the possibility of adding nutrients with other products in the spray solution (Fernández et al., 2013).

In order to improve the effectiveness of foliar sprays, micronutrients that present low mobility in the phloem should be applied to the main vegetation flushes (Spring and Summer), when the leaves are still young and have little developed cuticle, which facilitates absorption and supplies more efficiently the micronutrients to new developing organs (Boaretto et al., 2002, 2004). In addition, it should be noted that leaf nutrient sprays are often applied as mixtures in the spray tank with adjuvants and agricultural pesticides. Therefore, efficacy of foliar fertilizers, in combination with some adjuvants and plant protection products, may differ from when the nutrients are applied alone (Fernández et al., 2013). In this way, the compatibility between the fertilizer source and the pesticides is of paramount importance, so that one product does not interfere with the efficiency of the other. 
The validation of the efficacy of microparticulate and nanoparticulate sources is important to improve aspects of foliar spraying, since these fertilizers have a stable suspension capacity and controlled solubility in aqueous solution, which decrease the interaction with other spray products, reducing problems in the area of application technology. They also have very low phytotoxicity even at high concentrations applied in young leaves, when compared to the soluble sources (Li et al., 2012). Since the total amount of ions absorbed by the leaves is limited by the area of the cuticle covered by the sprayed solutes, the effectiveness of the sparingly soluble suspensions can potentially be improved by increasing the leaf spray area, which is a better strategy than increasing the micronutrient concentrations in the solution (Du et al., 2015).

Zinc oxide is among the most widely used manufactured nanoparticles in industrial, commercial, and medicinal products. In a recent study, it was suggested that $\mathrm{ZnO}$ nanoparticles may have potential as fertilizers of improved effectiveness for foliage application. A single foliar spray of $\mathrm{Zn}$ and B nanoparticulate increased the concentration of the micronutrient in the pomegranate leaves, with increasing from the control to the higher doses (Davarpanah et al., 2016). Leaf sprays with $\mathrm{ZnO}$ in nanoparticles led to a $26-30 \%$ increase in peanut yield when compared to $\mathrm{ZnSO}_{4}$ used at higher doses in two different seasons (Prasad et al., 2012).

Sparingly soluble fertilizers maintain nutrient support to the plant for a long time and reduce the risk of toxicity immediately after application, as well as reduce the frequency of application (Westfall et al., 1999). In sparingly soluble fertilizers, the particles adhered to the leaf surface can serve as a solid phase to restore the micronutrient content during a growth phase, due to the fact that the particles are strongly retained on the leaf surface during a long term (Fernández \& Brown, 2013; Du et al., 2015).

In contrast, foliar application of soluble sources generally results in higher uptake of the micronutrient by the leaves compared to a suspension of low solubility source, at a first moment (Zhang \& Brown, 1999; Erenoglu et al., 2002; Peryea, 2006), but soon, there is a decrease in the rate of absorption by leaves (Du et al., 2015). Also, a common symptom of toxicity in the application of foliar fertilizers is the occurrence of "leaf burning", which may be a consequence of cell disruption due to large differences in osmotic pressure across the cell wall, especially in younger leaves (Greenway \& Munns, 1980). This type of damage has higher occurrence with compounds of high salt index (Clapp, 2009).

Foliar absorption of sparingly soluble fertilizers in suspension will be influenced by relative humidity and POD as discussed above. After the deposition of the suspended particles on the leaf surface, it is expected that the moisture at the contact interface between the fertilizer particles and the leaf surface will create a situation similar to a saturation state (Boulard et al., 2002, 2004) (Figure 2). The foliar absorption rate and the dissolution of particles deposited on the surface after the foliar treatment are improved under high relative humidity (Schönherr, 2001, 2006).

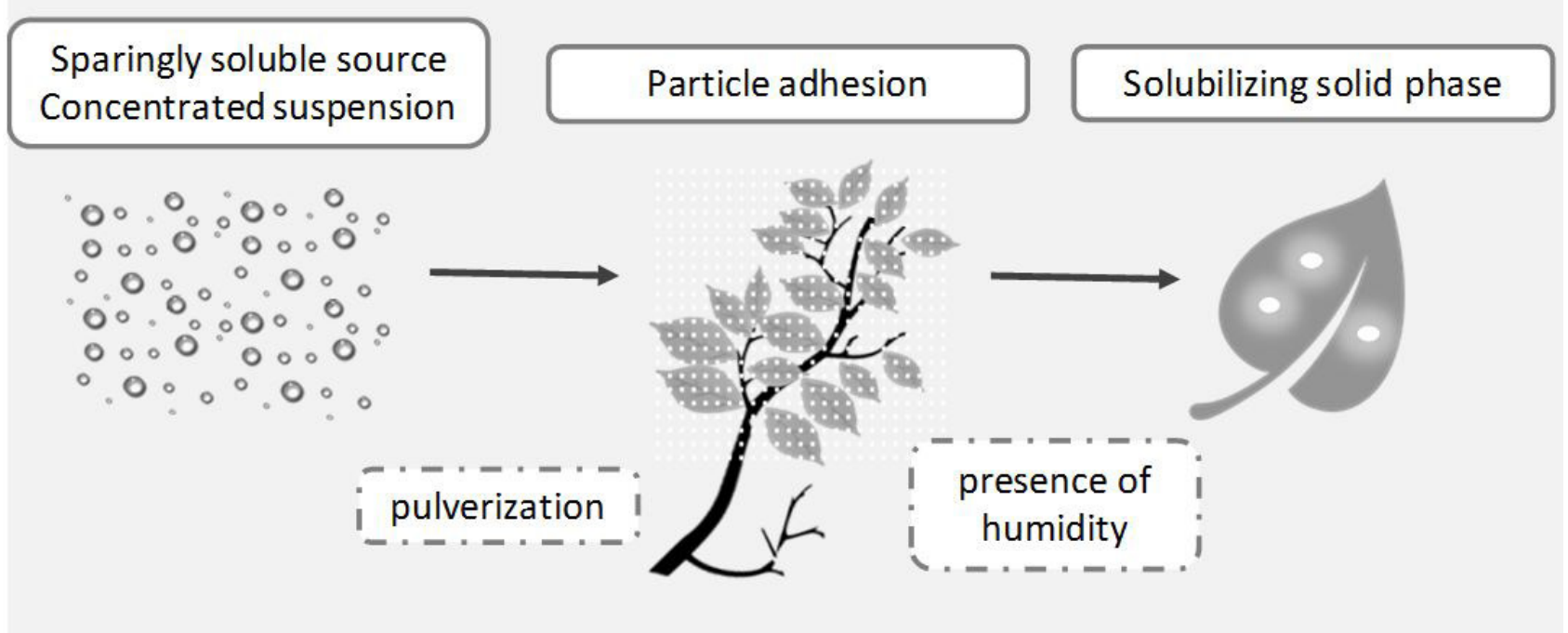

Figure 2. Scheme for the availability of sparingly soluble sources of micronutrients applied in leaves. Source: Authors. 


\section{THE BRAZILIAN REGULATORY ISSUES}

According to the Normative No. 5, February 23, 2007 (Brasil, 2007), of the Ministry of Agriculture, Livestock and Supply in Brazil (MAPA 2007) that rules definitions and standards for specifications and guarantees, tolerances, registration, packaging and labeling of mineral fertilizers, intended for agriculture - mineral fertilizers, when destined to the foliar application must present nutrients totally soluble in water with minimum concentration guarantees declared: $0.02 \%$ of $\mathrm{B}, 0.1 \% \mathrm{Mn}, 0.05 \mathrm{Cu}$ and $0.1 \% \mathrm{Zn}$ in solid products and $0.01 \%$ of $\mathrm{B}, 0.02 \% \mathrm{Mn}, 0.05 \% \mathrm{Cu}$ and $0.1 \% \mathrm{Zn}$ in fluid products. Thus, the registration of fertilizer sources for foliar application is restricted to those soluble in water, limiting the registration of sparingly soluble sources independently of their micronutrient supply efficiency and benefits in the application. For soil application, micronutrients products must have at least $60 \%$ of the nutrient content soluble in a solution containing $2 \%$ of citric acid.

\section{SPARINGLY SOLUBLE SOURCES IN FOLIAR APPLICATION FOR CITRUS: PRELIMINARY RESULTS}

In an experiment carried out with nursery citrus plants, comparing two sources of $\mathrm{Cu}$, a water-soluble (Cu sulfate) and a sparingly soluble ( $\mathrm{Cu}$ oxicarbonate) with $\mathrm{Cu}$ in microparticles, leaf sprayed of solution with low $\left(50 \mathrm{mg} \mathrm{L}^{-1}\right)$, adequate $\left(100 \mathrm{mg} \mathrm{L}^{-1}\right)$ and high (200 $\mathrm{mg} \mathrm{L}^{-1}$ ) concentration of $\mathrm{Cu}$, and a non-sprayed control, the results showed that both $\mathrm{Cu}$ sources have provided adequate concentrations of the micronutrient in the leaves and increase concentration in wood parts. Although, the plants fertilized with $\mathrm{Cu}$ sulfate showed higher concentration of the micronutrient in leaves and wood parts and higher indirect content of chlorophyll (SPAD) than those fertilized with $\mathrm{Cu}$ microparticulate. The dry matter of the canopy increase with increasing in the $\mathrm{Cu}$ dose without difference between sources, showing that the $\mathrm{Cu}$ is fulfilling its role in the development of citrus with both sources applied (Unpublished data).

In similar circumstances, but with $\mathrm{B}$ and $\mathrm{Zn}$, other two experiments were carried out comparing different micronutrients sources; two water-soluble ( $\mathrm{Zn}$ sulfate and boric acid) and an insoluble source ( $\mathrm{Zn}$ borate) as microparticles. Each source was leaf sprayed at a low (43 $\mathrm{mg} \mathrm{L}^{-1} \mathrm{~B} ; 200 \mathrm{mg} \mathrm{L}^{-1} \mathrm{Zn}$ ), adequate (129 $\mathrm{mg} \mathrm{L}^{-1} \mathrm{~B}$; $\left.600 \mathrm{mg} \mathrm{L}^{-1} \mathrm{Zn}\right)$ and high (387 $\left.\mathrm{mg} \mathrm{L}^{-1} \mathrm{~B} ; 1800 \mathrm{mg} \mathrm{L}^{-1} \mathrm{Zn}\right)$ concentration of $\mathrm{B}$ and $\mathrm{Zn}$; a non-sprayed control was also evaluated. According to what occurred with the micronutrient $\mathrm{Cu}$, the soluble source provided higher leaf content of B with the highest dose compared to the others. In contrast, $\mathrm{Zn}$ reached higher leaf content with the highest dose of $\mathrm{Zn}$ borate. Both sources provided increased concentrations of $\mathrm{B}$ and $\mathrm{Zn}$ with increased doses applied in the leaves, and the sources increased $\mathrm{Zn}$ in woods with increasing dose, without differences between the sources. Plants showed an increase in leaf area and dry matter of canopy up to the adequate dose for both sources, and in the high dose, these parameters, present a decrease due to excess $\mathrm{Zn}$ micronutrient, mainly in the $\mathrm{Zn}$ borate source, validating the $\mathrm{Zn}$ activity from the sparingly soluble fertilizer.

\section{PERSPECTIVES}

In this paper, we reinforce the necessity to validate the efficacy of micro and nanoparticulate sources, as well as, to develop new fertilizer sources to improve the availability of micronutrients to citrus in both, soil and foliar application. Although the first results are satisfactory with regard to the possibility of using sparingly soluble sources of micronutrients in soil and foliar applications, further studies, that validate the efficiency of these sources, mainly for the registration of foliar use, are still necessary.

\section{REFERENCES}

Abreu CA, Van Raij B \& Tanaka RT (1996) Fontes de manganês para soja e seus efeitos na análise do solo. Revista Brasileira de Ciência do Solo 20: 91-97.

Alloway BJ (2008). Zinc in soils and crop nutrition. Brussels: International Zinc Association.

Batsmanova LM, Gonchar LM, Taran NY \& Okanenko AA (2013). Using a colloidal solution of metal nanoparticles as micronutrient fertiliser for cereals. Proceedings of the International Conference Nanomaterials: Applications and Properties, Crimea, Ukraine.

Bell RW \& Dell B (2008). Micronutrients for sustainable food, feed, fibre and bioenergy production. Paris: International Fertilizer Industry Association. 
Boaretto AE, Boaretto RM, Contin TLM \& Muraoka T (2004) É móvel ou imóvel o boro em laranjeiras? Laranja 25: 195-208.

Boaretto AE, Boaretto RM, Muraoka T, Nascimento Filho VF, Tiritan CS \& Mourão Filho FAA (2002) Foliar micronutrient application effects on citrus fruit yield, soil and leaf concentrations and 65Zn mobilization within the plant. Acta Horticulturae (594): 203-209. http://dx.doi. org/10.17660/ActaHortic.2002.594.22.

Boulard T, Fatnassi H, Roy JC, Lagier J, Fargues J, Smits N, Rougier M \& Jeannequin B (2004) Effect of greenhouse ventilation on humidity of inside air and in leaf boundarylayer. Agricultural and Forest Meteorology 125(3-4): 225239. http://dx.doi.org/10.1016/j.agrformet.2004.04.005.

Boulard T, Mermier M, Fargues J, Smits N, Rougier M \& Roy JC (2002) Tomato leaf boundary layer climate: implications for microbiological whitefly control in greenhouses. Agricultural and Forest Meteorology 110(3): 159-176. http://dx.doi.org/10.1016/S0168-1923(01)00292-1.

Bradl HB (2004) Adsorption of heavy metal ions on soils and soils constituents. Journal of Colloid and Interface Science 277(1): 1-18. PMid:15276031. http://dx.doi. org/10.1016/j.jcis.2004.04.005.

Brasil. Ministério da Agricultura, Pecuária e Abastecimento - MAPA. Instrução normativa ${ }^{\circ}{ }^{5}$, de 23 de fevereiro de 2007. Diário Oficial da República Federativa do Brasil, Brasília, DF, 1 mar. 2007.

Camargo OA(1991). Reações e interações de micronutrientes no solo. In: Ferreira ME \& Cruz MCP(Eds). Micronutrientes na agricultura. Piracicaba: Potafós/CNPq, p. 233-272.

Clapp JG (2009) Let's be careful when defining salt index. Fluid Journal 17(4).

Davarpanah S, Tehranifar A, Davarynejad G, Abadía J \& Khorasani R (2016) Effects of foliar applications of zinc and boron nano-fertilizers on pomegranate (Punica granatum cv. Ardestani) fruit yield and quality. Scientia Horticulturae 210: 57-64. http://dx.doi.org/10.1016/j. scienta.2016.07.003.

DeRosa MC, Monreal C, Schnitzer M, Walsh R \& Sultan Y (2010) Nanotechnology in fertilizers. Nature Nanotechnology 5(2): 91. PMid:20130583. http://dx.doi. org/10.1038/nnano.2010.2.

Dias MAN \& Cicero SM (2016) Effect of copper carbonate and zinc oxide applied to seeds on copper and zinc uptake by maize seedlings. Bragantia 75(3): 286-291.
Du Y, Li P, Nguyen AV, Xu ZP, Mulligan D \& Huang L (2015) Zinc uptake and distribution in tomato plants in response to foliar supply of $Z n$ hydroxide-nitrate nanocrystal suspension with controlled Zn solubility. Journal of Plant Nutrition and Soil Science 178(5): 722-731. http://dx.doi. org/10.1002/jpln.201400213.

Erenoglu B, Nikolic M, Römheld V \& Cakmak I (2002) Uptake and transport of foliar applied zinc (65Zn) in bread and durum wheat cultivars differing in zinc efficiency. Plant and Soil 241(2): 251-257. http://dx.doi. org/10.1023/A:1016148925918.

Fageria NK, Barbosa Filho M, Moreira A \& Guimarães CM (2009) Foliar fertilization of crop plants. Journal of Plant Nutrition 32(6): 1044-1064. http://dx.doi. org/10.1080/01904160902872826.

Fagundes AV, Garcia AWR \& Matiello JB (2010). Comparação de fontes de fertilizantes de micronutrientes comerciais, com a recomendação tradicional de sais para o cafeeiro. Boa Esperança: SBICafé. (Folha Técnica Procafé MAPA).

Fernández V \& Brown PH (2013) From plant surface to plant metabolism: the uncertain fate of foliar-applied nutrients. Frontiers in Plant Science 4: 1-289. PMid:23914198. http://dx.doi.org/10.3389/fpls.2013.00289.

Fernández V \& Eichert T (2009) Uptake of hydrophilic solutes through plant leaves: current state of knowledge and perspectives of foliar fertilization. Critical Reviews in Plant Sciences 28(1-2): 36-68. http://dx.doi. org/10.1080/07352680902743069.

Fernández V, Sotiropoulos T \& Brown PH (2013). Foliar fertilisation: principles and practices. Paris: International Fertilizer Industry Association.

Gangloff WJ, Westfall DG, Peterson GA \& Mortvedt JJ (2002) Relative availability coefficients of organic and inorganic Zn fertilizers. Journal of Plant Nutrition 25(2): 259-273. http://dx.doi.org/10.1081/PLN-100108834.

Greenway H \& Munns R (1980) Mechanisms of salt tolerance in nonhalophytes. Annual Review of Plant Physiology 31(1): 149-190. http://dx.doi.org/10.1146/ annurev.pp.31.060180.001053.

Hippler FWR, Boaretto RM, Quaggio JA, Azevedo RA \& Mattos Junior D (2015a) Towards soil management with $\mathrm{Zn}$ and $\mathrm{Mn}$ : estimates of fertilisation efficacy of citrus trees. Annals of Applied Biology 166(3): 484-495. http://dx.doi.org/10.1111/aab.12197. 
Hippler FWR, Boaretto RM, Quaggio JA, Boaretto AE, Abreu-Junior CH \& Mattos Junior D (2015b) Uptake and distribution of soil applied zinc by citrus trees: addressing fertilizer use efficiency with $68 \mathrm{Zn}$ labeling. PLoS One 10(3): e0116903. PMid:25751056. http:// dx.doi.org/10.1371/journal.pone.0116903.

Li P, Xu ZP, Hampton MA, Vu DT, Huang L, Rudolph V \& Nguyen AV (2012) Control preparation of zinc hydroxide nitrate nanocrystals and examination of the chemical and structural stability. The Journal of Physical Chemistry C 116(18): 10325-10332. http://dx.doi.org/10.1021/jp300045u.

Lindsay WL (1979). Chemical equilibria in soils. New York: John Wiley \& Sons.

Luchese AV, Gonçalves Junior AC, Luchese EB \& Braccini MCL (2004) Emergência e absorção de cobre por plantas de milho (Zea mays) em resposta ao tratamento de sementes com cobre. Ciência Rural 34(6): 1949-1952. http://dx.doi.org/10.1590/S0103-84782004000600044.

McBeath TM \& McLaughlin MJ (2014) Efficacy of zinc oxides as fertilisers. Plant and Soil 374(1-2): 843-855. http://dx.doi.org/10.1007/s11104-013-1919-2.

Moran K (2004). Micronutrient product types and their development. York: International Fertiliser Society.

Moran K (2006). Main micronutrient forms/products available and methods of application. Proceedings of the IFAAgriculture Conference Workshop on Micronutrients: Optimizing Resource Use Efficiency for Sustainable Intensification of Agriculture, Kunming, China.

Mosanna R \& Khalilvand BE (2015) Morpho-physiological response of maize (Zea mays L.) to zinc nano-chelate foliar and soil application at different growth stages. Journal on New Biological Reports 4: 46-50.

Naderi M, Danesh Shahraki AA \& Naderi R (2011) Application of nanotechnology in the optimization of formulation of chemical fertilizers. Iranian Journal of Nanotechnology 12: 16-23.

Obreza TA, Zekri M, Hanlon EA, Morgan K, Schumann A \& Rouse R (2010) SL253.04: soil and leaf tissue testing for commercial citrus production. Florida: University of Florida Extension Service.

Peryea FJ (2006) Phytoavailability of zinc in postbloom zinc sprays applied togolden delicious' apple trees. HortTechnology 16(1): 60-65.
Prado RM, Natale W \& Mouro MC (2007) Fontes de zinco aplicado via semente na nutrição e crescimento inicial do milho cv. Fort. Bioscience Journal 23: 16-24.

Prasad TNVKV, Sudhakar P, Sreenivasulu Y, Latha P, Munaswamy V, Reddy KR, Sreeprasad TS, Sajanlal PR \& Pradeep T (2012) Effect of nanoscale zinc oxide particles on the germination, growth and yield of peanut. Journal of Plant Nutrition 35(6): 905-927. http://dx.doi.org/10.1 080/01904167.2012.663443.

Quaggio, JA., Mattos Junior, D., and Boaretto, R. M. (2010). Citros. In: Boas práticas para uso eficiente de fertilizantes. Georgia: IPNI, p. 371-409. v. 1.

Quaggio JA, Mattos Junior D, Cantarella H \& Tank Junior A (2003) Fertilização com boro e zinco no solo em complementação à aplicação via foliar em laranjeira Pêra. Pesquisa Agropecuária Brasileira 38(5): 627-634. http://dx.doi.org/10.1590/S0100-204X2003000500011.

Quaggio JA \& Piza CTJ (2001). Frutíferas Tropicais. In: Ferreira ME, Cruz MCP, Van Raij B \& Abreu CA (Eds). Micronutrientes e elementos tóxicos na agricultura. Jaboticabal: CNPq/FAPESP/POTAFOS, cap. 18, p. 459-492.

Schönherr J (2001) Cuticular penetration of calcium salts: effects of humidity, anions, and adjuvants. Journal of Plant Nutrition and Soil Science 164(2): 225-231. http:// dx.doi.org/10.1002/1522-2624(200104)164:2<225::AIDJPLN225>3.0.CO;2-N.

Schönherr J (2006) Characterization of aqueous pores in plant cuticles and permeation of ionic solutes. Journal of Experimental Botany 57(11): 2471-2491. PMid:16825315. http://dx.doi.org/10.1093/jxb/erj217.

Shaver TM, Westfall DG \& Ronaghi M (2007) Zinc fertilizer solubility and its effects on zinc bioailability over time. Journal of Plant Nutrition 30(1): 123-133. http://dx.doi.org/10.1080/01904160601055145.

Slaton NA, Gbur EE, Wilson CE \& Norman RJ (2005) Rice response to granular zinc sources varying in watersoluble zinc. Soil Science Society of America Journal 69(2): 443-452. http://dx.doi.org/10.2136/sssaj2005.0443.

Subramanian KS \& Sharmila Rahale C (2012) Ball milled nanosized zeolite loaded with zinc sulfate: a putative slow release $\mathrm{Zn}$ fertilizer. International Journal of Innovative Horticulture 1: 33-40.

Subramanian KS, Manikandan A, Thirunavukkarasu M \& Rahale CS (2015). Nano-fertilizers for balanced crop nutrition. In: Rai M, Ribeiro C, Mattoso L \& Duran N 
(Eds). Nanotechnologies in food and agriculture. Springer International Publishing, p. 69-80.

Tezotto T, Favarin JL, Azevedo RA, Alleoni LRF \& Mazzafera P (2012) Coffee is highly tolerant to cadmium, nickel and zinc: plant and soil nutritional status, metal distribution and bean yield. Field Crops Research 125: 25-34. http://dx.doi.org/10.1016/j.fcr.2011.08.012.

Volkweiss SJ (1991). Fontes e métodos de aplicação. In: Ferreira ME \& Cruz MCP (Eds). Micronutrientes na agricultura. Piracicaba: Potafos/CNPq, p. 391-412.

Westfall DG, Amrani M \& Peterson GA (1999) Watersolubility of zinc fertilizer: does it matter? Better Crops with Plant Food 83(2): 18-20.
Wiesner MR, Lowry GV, Alvarez P, Dionysiou D \& Biswas P (2006) Assessing the risks of manufactured nanomaterials. Environmental Science \& Technology 40(14): 4336-4345. PMid:16903268. http://dx.doi. org/10.1021/es062726m.

Zekri M \& Obreza TA (2003). Micronutrient deficiencies in citrus: boron, copper, and molybdenum. Florida: EDIS, Institute of Food and Agricultural Sciences, University of Florida Cooperative Extension Service.

Zhang Q \& Brown PH (1999) Distribution and transport of foliar applied zinc in pistachio. Journal of the American Society for Horticultural Science 124(4): 433-436.

Received: February 16, 2017 Accepted: November 04, 2017 